\title{
Web Service Processor sebagai Penghubung Sistem Kiosk Medicom dengan SIM RS Kanker Dharmais
}

\author{
Barizana Sukmadewi Arifin, Mauldy Laya \\ Jurusan Teknik Informatika dan Ko mputer \\ Politeknik Negeri Jakarta \\ Jl. Prof. Dr. G.A Siwabessy, Kampus Baru UI, Beji, Ku kusan, Beji, Kota Depok, Jawa Barat, Indonesia \\ sbarizana@g mail.com,dylaya@g mail.com
}

Diterima: 16 Agustus 2017. Disetujui: 12 September 2017. Dipublikasikan: November 2017

\begin{abstract}
Abstrak - Badan Penyelenggara Jaminan Sosial (BPJS) merupakan badan penyelenggara jaminan kesehatan untuk masyarakat Indonesia. BPJS difungsikan untuk membantu dan mempermudah masyarakat untuk mendapatkan layanan kesehatan yang sesuai dari penyedia layanan kesehatan. Namun, hal baik ini berdampak pada peningkatan jumlah ratarata pasien di Rumah Sakit Kanker Dharmais (RS KD) tiap harinya. Sementara penyisipan informasi pasien masih dilakukan secara manual oleh pegawai RSKD. Sistem KIOSK Medicom membantu untuk meningkatkan pelayanan pendaftaran pada RSKD. Pembuatan web service ini memungkinkan sistem KIOSK Medicom dapat mengakses dan melakukan pengecekan informasi pasien yang berada dalam SIM RS KD, pengecekan selesainya tiga status episode dari riwayat kegiatan pasien terdahulu, pendaftaran pasien ke dalam poli tujuan dan dokter yang dipilih, pencetakan SEP, dan penyimpanan data pendaftaran pasien. Komponen yang digunakan untuk perancangan web service ini adalah bahasa pemrograman Java dengan framework Spring, Eclipse arsitektur RES T web service, Postman, dan database SQL Server.
\end{abstract}

Kata Kunci : bpjs, rumah sakit, web service, java, rest.

\section{PENDAHULUAN}

Pada era globalisasi hampir segala bidang kehidupan manusia telah tersentuh oleh Teknologi Informasi (TI), hingga sampai pada bidang kesehatan. Alasan utama TI merambah bidang ini ialah disebabkan oleh teknologi yang mampu meningkatkan kualitas pelayanan, khususnya dalam pelayanan dari penyedia layanan kesehatan. Badan Penyelenggara Jaminan Sosial (BPJS) merupakan salah satu badan penyelenggara jaminan kesehatan untuk masyarakat Indonesia. BPJS difungsikan untuk membantu dan mempermudah masyarakat untuk mendapatkan layanan kesehatan yang sesuai dari penyedia layanan kesehatan. Rumah sakit sebagai salah satu penyedia layanan kesehatan di Indonesia mendapat pengaruh dengan adanya bantuan jaminan kesehatan BPJS ini. Pengaruh tersebut adalah peningkatan jumlah pasien yang meningkat pesat, tidak terkecuali dengan Rumah Sakit Kanker Dharmais (RSKD). RSKD memiliki rata-rata ju mlah pasien 800 sampai dengan 1000 pasien tiap harinya. Pasien-pasien tersebut harus didaftarkan terlebih dahulu sehingga dapat menerima pelayanan kesehatan. Namun, RSKD kewalahan dengan jumlah pendaftar yang ada. Sedangkan pelayanan kurang optimal dan terbilang lamban untuk sistem pendaftaran dan pencetakan Surat Eligibilitas Peserta (SEP) dengan jumlah pasien yang begitu besar. Hal itu disebabkan karena penyisipan informasi pasien masih dilakukan secara manual oleh pegawai RSKD.

Dengan adanya masalah tersebut, sistem KIOSK hadir untuk meningkatkan pelayanan pendaftaran pada RSKD. Sistem KIOSK berada di bawah naungan tim Medicom dari PT. Indo Medika Utama, yang bekerjasama dengan Panasonic Healthcare dari Jepang dan PT. Gobel Dharma Nusantara. Untuk dapat melakukan pendaftaran melalui sistem KIOSK, diperlukan suatu media komunikasi. Salah satunya dengan penggunaan web service. Web service dapat membuat sistem KIOSK menjadi terintegrasi dengan Sistem Informasi Manajemen (SIM) RSKD. Pembuatan web service ini dibagi menjadi dua bagian, yaitu web service processor dan web service adapter. Penelitian ini menitikberatkan pada pengerjaan web service processor. 


\section{TINJAUAN PUSTAKA}

\section{A. Web Service}

Web service merupakan layanan atau aplikasi client dan server, yang berkomunikasi dan bertukar informasi melalui World Wide Web (WWW). Client mengirimkan permintaan melalui web dan server menerima permintaan memprosesnya dan mengembalikan sebuah respon. Web service menyimpan data informasi dalam format JSON atau XML, sehingga memungkinkan interaksi pada sistem yang berbeda platform, sistem operasi, dan bahasa pemrograman [1]. Berikut arsitektur web service secara umu m:

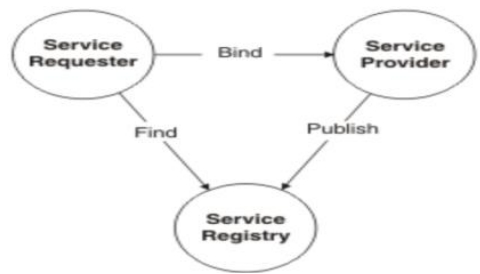

Gambar 1. Arsitektur Web Service[1]

Pada Gambar 1 terdapat tiga komponen arsitektur utama dari web service yaitu[1]:

a. Service provider sebagai penyedia web service yang berfungsi menyediakan kumpulan web service yang dapat diakses oleh pengguna.

b. Service requestor, yang merupakan aplikasi yang bertindak sebagai pengguna yang melakukan permintaan layanan (berupa web service) service provider.

c. Service registry, yang merupakan tempat dimana service provider mempublikasikan layanannya. Pada arsitektur Web service, Service registry bersifat opsional.

\section{REST Web Service}

REST web service merupakan seperangkat prinsip arsitektur yang dapat digunakan untuk merancang web service yang berfokus pada sumber daya (resource). Sama seperti arsitektur client/server web pada umumnya, request dan response digunakan untuk mengirim resource atau data. REST bersifat stateless dan resource-oriented. REST web service memiliki 4 prinsip utama [2], yaitu:

a. Menggunakan HTTP method secara eksplisit. Salah satu karakteristik utama dari layanan REST adalah penggunaan HTTP method secara eksplisit dengan cara yang mengikuti protokol seperti yang didefinisikan oleh Request for Comments (RFC) 2616.

b. Stateless meningkatkan kinerja dan menyederhanakan desain aplikasi REST web service. Hal ini dikarenakan dengan tidak adanya state server tidak perlu melakukan sinkronisasi session data dengan aplikasi klien.

c. Mengekspose struktur direktori. REST web service harus memiliki Uniform Resource Identifier (URI) yang intuitif dan mudah ditebak. URI didefinisikan sebagai semacam dokumentasi diri antarmuka yang memerlukan sedikit, jika ada, penjelasan atau referensi bagi sumber daya yang terkait.

d. Bertukar data dengan menggunakan XML, Java Script Object Notation (JSON) atau keduanya.

\section{Postman}

Postman adalah sebuah aplikasi (berupa plugin) untuk browser chrome, yang berfungsi sebagai REST Client, yang digunakan untuk melakukan uji coba REST API [3]. Postman juga dapat diunduh sebagai aplikasi dekstop. Postman merupakan platform GUI yang powerful untuk membuat pengembangan API lebih cepat dan mudah, mulai dari membangun API melalui testing, dokumentasi, dan sharing. Postman direkomendasikan untuk sistem operasi Mac, Windows atau juga Linu x.

\section{B. Java}

Java adalah sebuah bahasa pemrograman yang diciptakan oleh James Gosling, seorang developer dari Sun Microsystem pada tahun 1991. Java memiliki beberapa keunggulan seperti berbasis GUI (Graphical User Interface), aplikasi web, multiplatform, bisa digunakan pada aplikasi jaringan terdistribusi serta multithread [4].

\section{Apache Tomcat}

Apache Tomcat merupakan sebuah web server yang bersifat open-source yang mendukung untuk penggunaan spesifikasi Java EE antara lain Java Servlet, Java Server Pages (JSP), Java Expression Language, WebSocket, dan menyediakan sebuah environment HTTP web server murni Java dimana aplikasi berbasis Java dapat dijalan kan.

\section{Spring}

Spring merupakan salah satu framework milik Java yang ringan, berkinerja baik, mudah diuji, dan kode dapat digunakan kembali. Spring juga memiliki kerangka kerja open source, yang diciptakan oleh Rod Johnson untuk menyelesaikan masalah desain sistem dalam penge mbangan aplikasi enterprise.

\section{Eclipse}

Eclipse adalah sebuah IDE (Integrated Development Environment) untuk mengembangkan perangkat lunak dan dapat dijalankan di semua 
platform[5]. Eclipse sering disebut dengan IDE untuk para developer Java. Eclipse merupakan salah satu produk yang dikembangkan dan diluncurkan oleh IBM pada tanggal 5 November 2001.

\section{SQL Server}

SQL Server adalah Relational Data Base Management System (RDBMS) yang dapat mendukung beragam pemrosesan transaksi, Business Intelligent (BI) dan aplikasi analisis di bagian TI dalam perusahaan. Basis data (data base) sebagai kumpulan data berisi informasi yang sesuai untuk sebuah perusahaan. Sistem manajemen database adalah kumpulan data yang saling berhubungan dan kumpulan program untuk mengakses data[6]. SQL Server merupakan salah satu dari tiga database terdepan dalam perkembangan pasar saat ini, bersama dengan Oracle Database dan IBM's DB2. Berikut in i adalah beberapa keunggulan SQL Server:

a. Mampu untuk manajemen user dan tiap user dapat diatur hak akses terhadap suatu data base oleh data base administrator.

b. Mampu untuk membuat data base mirroring dan clustering.

c. Tingkat security data yang baik.

d. Mampu untuk back up data, rollback data, dan recovery data.

e. Cocok untuk perusahaan dengan skala kecil, menengah, dan besar mampu untuk mengolah data dengan jumlah yang besar.

Namun dengan keunggulan tersebut, untuk dapat mengakses pada SQL Server pada Bahasa pemrograman Java dibutuhkannya driver, yaitu JDBC. JDBC merupakan salah satu API (Application Programming Interface) Java yang secara khusus ditujukan untuk menangani koneksi ke data base[7].

\section{Surat Eligibiitas Peserta (SEP)}

Surat Elig ibiitas Peserta (SEP) merupakan surat yang diterbitkan untuk mempermudah peserta BPJS memperoleh layanan kesehatan, khususnya pada fasilitas kesehatan (faskes) tingkat lanjutan seperti faskes tingkat II di Rumah Sakit Umum Daerah, Rumah Sakit Swasta serta Rumah Sakit Umum Pemerintah dan fasilitas III tingkat lanjutan seperti Rumah Sakit Nasional (RSJP, RSKD dan RSCM).

SEP harus ada salah satunya sebagai identitas dan tanda bahwa pasien telah diverifikasi status kepesertaannya dan secara administrasi sah sebagai pasien yang dijamin oleh BPJS Kesehatan [3]. SEP merupakan surat untuk membuktikan bahwa pasien sah secara klaim administrasi. Namun, bila SEP sudah terbit, pasien belum tentu dapat lolos verifikasi klaim medis serta secara verifikasi administrasi. Sehingga SEP tidak dapat dijadikan sebagai bukti penjaminan peserta BPJS.

\section{E. $\quad U M L$}

UML adalah sebuah "bahasa" yang telah menjadi standar dalam industri untuk visualisasi, merancang dan mendokumentasikan sistem piranti lunak [4]. UML merupakan bahasa pemodelan untuk sistem atau perangkat lunak yang berhubungan tentang kata "berorientasi objek" untuk menggambarkan model spesifikasi, konstruksi, visualisasi dan dokumentasi bagi alur sistem perangkat lunak yang akan dikembangkan. Beberapa diagram yang digunakan pada penelitian ini adalah : Use case Diagram, Activity Diagram, Class Diagram, dan Sequence Diagram.

\section{HASIL DA N PEMBAHASAN}

\section{A. Analisa dan Perancangan}

Pada bagian analisa dan perancangan akan dijelaskan melalui diagram-diagram seperti Use Case Diagram, Activity Diagram, Class Diagram, Sequence Diagram dan struktur database untuk menggambarkan kegiatan dan bisnis proses pada web service processor.

1. Use Case Diagram

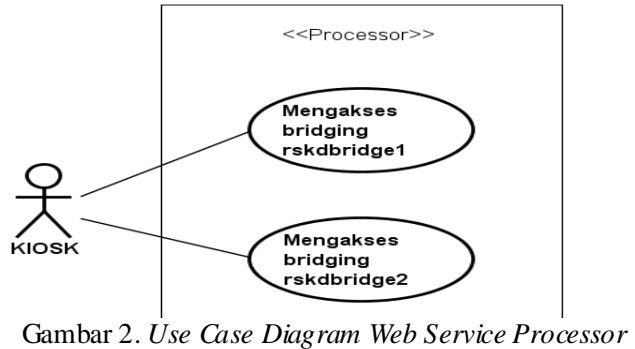

Gambar 6 merupakan gambaran dari kegiatan yang dapat dilakukan oleh aktor sistem KIOSK Medicom terhadap web service processor. Aktor dapat mengakases web service processor dengan cara memanggil URL yang mespesifikasikan proses bridging, agar terjadi pembatasan kegiatan sesuai dengan masing-masing fungsi, seperti proses bridging rskdbridgel dan rskdbridge2 . Web service processor dapat digunakan sebagai media komunikasi antara sistem KIOSK Medicom dengan web service RSKD dan web service BPJS untuk bertukar informasi.

\section{Activity Diagram}

Berikut adalah dua diagram aktivitas yang menggambarkan kegiatan dari use case di atas. Dua diagram aktivitas berikut terdiri dari dua proses 
kegiatan bridging yang dapat dilakukan oleh aktor, yaitu proses bridging rskdbridgel proses bridging dan rskdbridge 2 :

a. Aktivitas dalam bridging rskdbridge1 :

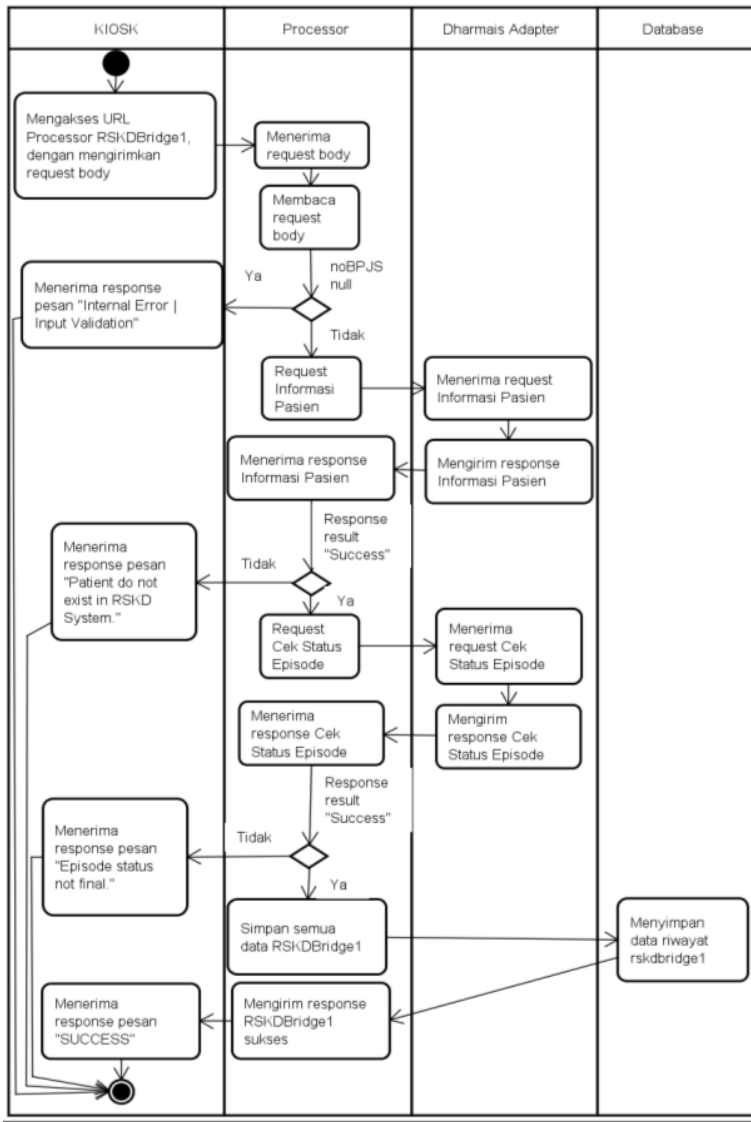

Gambar 3. Diagram Aktivit as Web Service ProcessorBridging Rskdbridgel

Gambar 7 menjelaskan proses rskdbridgel yang merupakan tahap awal dalam proses bridging pada web service processor. Dimulai dengan sistem KIOSK memberikan request body kepada web service processor yang akan diperiksa apakah request yang diberikan dapat dilanjutkan ke kegiatan berikutnya atau berhenti karena tidak mendapatkan respon yang seharusnya. Web service processor berinteraksi dengan web service Dharmais adapter untuk dapat melakukan request dan mendapatkan respon untuk mendapatkan informasi pasien RSKD dan cek status episode. Jika seluruh respon sesuai dengan yang diharapkan, maka seluruh data yang ada di dalam rskdbridgel akan disimpan di dalam database dengan nama tabel rskdbridgel history.

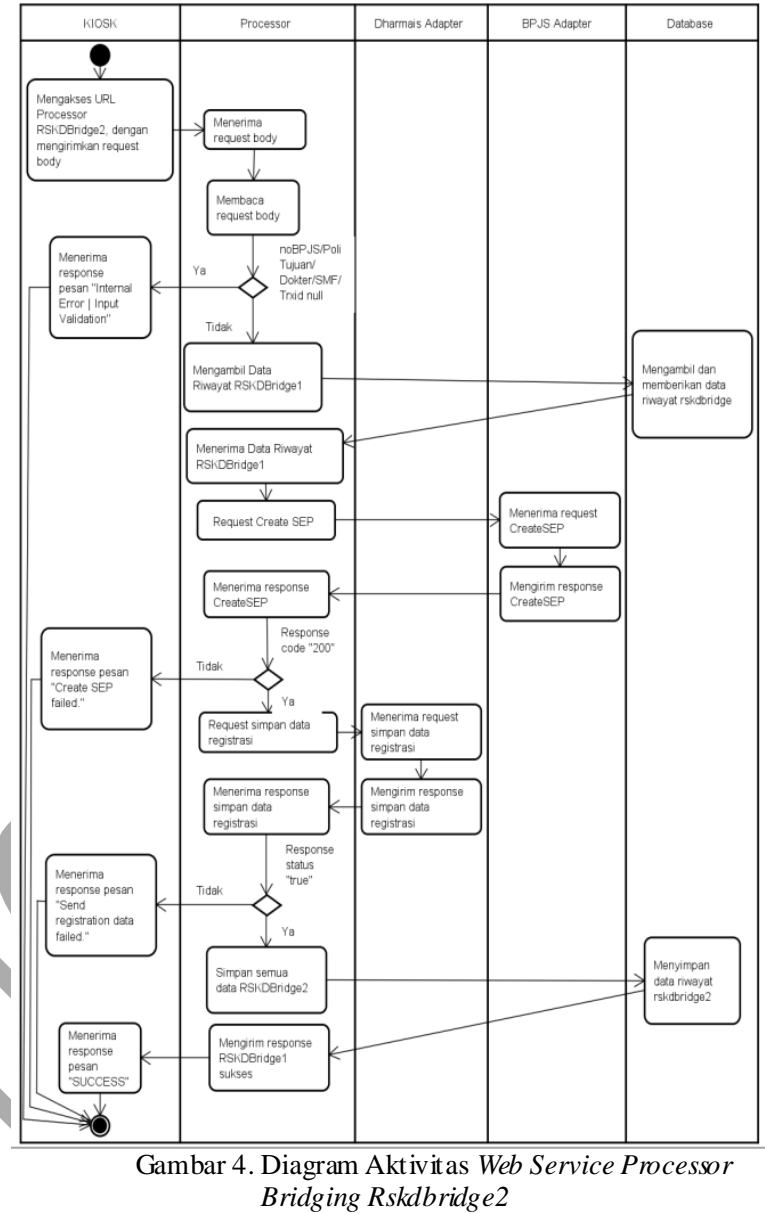

Gambar 8 menjelaskan proses bisnis untuk proses bridging rskdbridge2, KIOSK Medicom melakukan request untuk mendapatkan riwayat data dari proses bridging rskdbridgel, pembuatan SEP, melakukan request untuk mengirimkan data registrasi ke RSKD, melakukan validasi respon, hingga menyimpan data ke dalam database. Rskdbridge 2 memerlukan bantuan dari web service Dharmais adapter dan web service BPJS adapter untuk mencetak SEP. Dan terakhir akan disimpan di dalam tabel rskdbridge2 history.

\section{Sequence Diagram Web Service Processor}

Berikut adalah dua sequence diagram yang terdiri dari dua proses kegiatan bridging yang dapat dilakukan oleh aktor, yaitu rskdbridgel dan rskdbridge2 :

b. Aktivitas dalam bridging rskdbridge2 : 
a. Alur dalam bridging rskdbridgel :

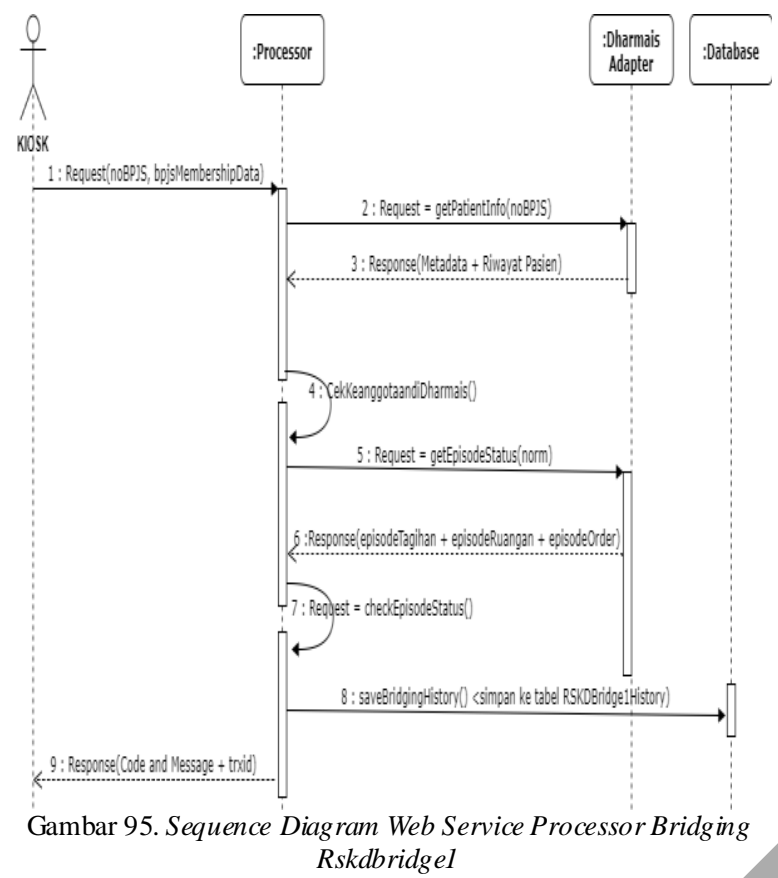

Gambar 9 menjelaskan proses bisnis untuk bridging rskdbridge1. Di mulai dari sistem KIOSK Medicom mengirimkan request dengan parameter noBPJS dan bpjsMembershipData yang dikirimkan kepada web service processor. Kemudian web service processor melakukan request kepada web service Dharmais adapter, untuk mendapatkan informasi pasien Dharmais lalu disaring respon yang didapat apakah dapat dilanjutkan ke tahap berikutnya, bila berhasil disaring akan dilakukan request kembali untuk mendapatkan tiga status episode, lalu respon kembali disaring. Sampai dengan proses tersebut, web service processor akan melakukan fungsi penyimpanan data untuk proes bridging rskdbridgel sebagai tanda bahwa proses bridging ini selesai dengan sukses. Data yang disimpan pada proses ini akan dijadikan informasi bagi proses bridging rskdbridge2, yaitu trxid. b. Alur dalam bridging rskdbridge2 :

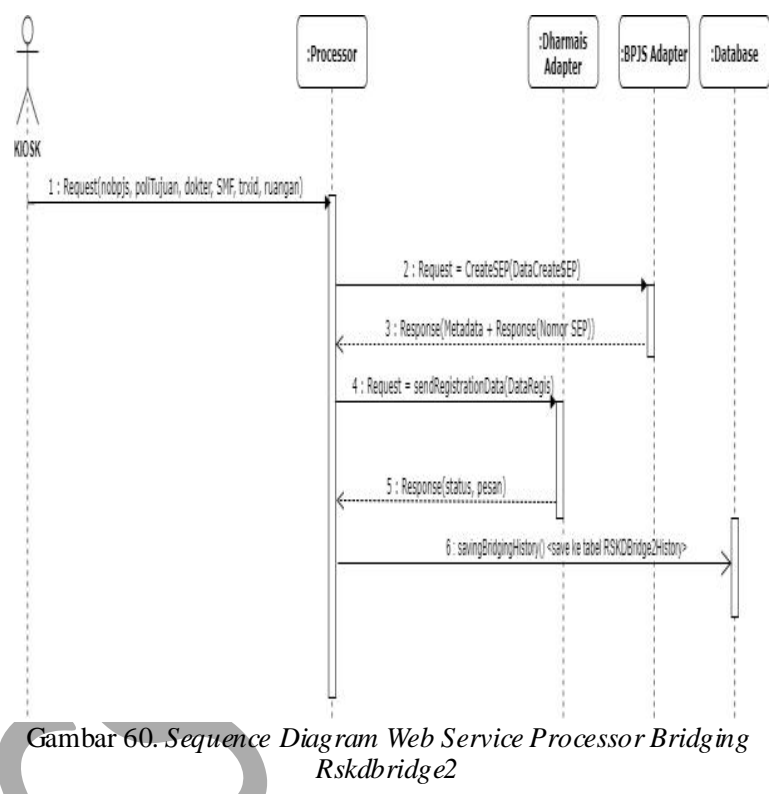

Gambar10 menjelaskan proses bisnis untuk bridging rskdbridge2, sistem KIOSK Medicom mengirimkan request dengan parameter nobpjs, poliTujuan, dokter, SMF, trxid, ruangan. Webservice Dharmais adapter dan BPJS adapter yang menerima request dan mengirimkan kembali respon untuk web service processor dan menyimpannya ke dalam tabel bridging rskdbridge2 history, sehingga dapat dinyatakan bahwa pendaftaran ke poli tujuan dan cetak SEP telah berhasil.

\section{B. Implementasi Web Service Processor}

Berikut adalah implementasi dari prosesproses yang dilakukan oleh web service processor:

a. Operasi bridging rskdbridge

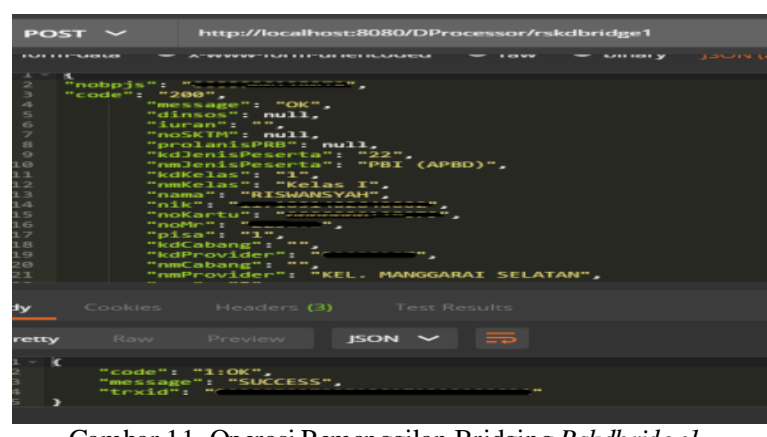

Gambar 11. Operasi Pemanggilan Bridging Rskdbridgel

Gambar 11 dari hasil pemanggilan fungsi proses bridging rskdbridgel pada web service 
processor yang berfungsi untuk menghasilkan cek kepesertaan di dalam SIM RSKD, cek episode apakah sudah pasien sudah selesai melakukan episode order, episode kunjungan, dan episode ruangan. Hasil dari proses ini adalah code, message, dan trxid.

b. Operasi bridging rskdbridge2

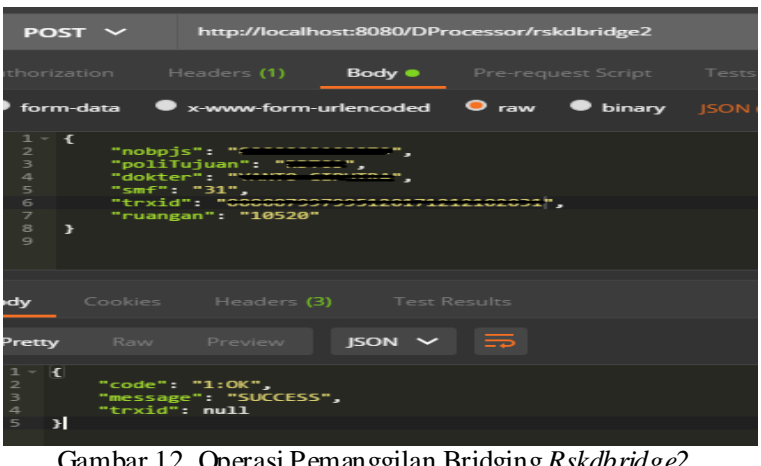

Gambar 12. Operasi Pemanggilan Bridging Rskdbridge2

Gambar 12 merupakan hasil pemanggilan dari fungsi bridging rskdbridge2 pada web service processor yang berfungsi untuk menentukan poli tujan dan dokter. Hasil dari proses ini adalah code, message, dan trxid.

\section{Pengujian Web Service Processor}

Pengujian yang dilakukan menggunakan menggunakan test case untuk mengetahui bagaimana hasil yang akan ditampilkan bila operasi bridging sesuai atau tidak sesuai dengan yang diinginkan. Format laporan pengujian disesuaikan dengan template yang telah dibuat sebagai panduan web service Medicom untuk PHC. Pengujian dilakukan terhadap requirement RSKD. Berikut adalah hasil pengujian dari rskdbridgel dan rskdbridge2:

a. Rskdbridgel

URL : <IP address>/DProcessor/rskdbridge1

Fungsi : Mendapatkan data informasi pasien RSKD, mengecek status episode dan simpan data bridging rskdbridge 1 .

Method :POST

Format : JSON
TABEL 1. TEST CASE OPERASI BRIDGING RSKDBRIDGE 1

\begin{tabular}{|c|c|c|c|c|}
\hline No. & $\begin{array}{l}\text { Test } \\
\text { Case }\end{array}$ & Request Parameter & $\begin{array}{l}\text { Response } \\
\text { Message }\end{array}$ & Type \\
\hline 1 . & $\begin{array}{l}\text { Rskd } \\
\text { bridg } \\
\text { el }\end{array}$ & $\begin{array}{l}\text { \{ "nobpjs": } \\
\text { "000xxxxxxxxxxx", } \\
\text { "code": "200", } \\
\text { "message": "OK", } \\
\text { "dinsos": null, "iuran" } \\
\text { "", "noSKTM": null, } \\
\text { "prolanisPRB": null, } \\
\text { "kdJenisPeserta": } \\
\text { "22", } \\
\text { "nmJenisPeserta": } \\
\text { "PBI (APBD)", } \\
\text { "kdKelas":"3", } \\
\text { "nmKelas": "KELAS } \\
\text { III", "nama": "TRI } \\
\text { ARNI", "nik": " } \\
\text { xxxxxxxxxxxxxxxxx" } \\
\text { "noKartu": } \\
\text { "000xxxxxxxxxx", } \\
\text { "noMr": "151515", } \\
\text { "pisa": "3", } \\
\text { "kdCabang": "', } \\
\text { "kdProvider": } \\
\text { "09020107", } \\
\text { "nmCabang": "'", } \\
\text { "nmProvider": "KEL. } \\
\text { MANGGARAI } \\
\text { SELAT AN", "sex": } \\
\text { "P", "keterangan": } \\
\text { "AKTIF", "kode": } \\
\text { "0", } \\
\text { "tglCetakKartu": } \\
\text { "2014-12-17", } \\
\text { "tglLahir": "1965-09- } \\
\text { 29", "tgIT AT": "2050- } \\
\text { 12-31", "tgITMT": } \\
\text { "2014-01-09 } \\
\text { "umurSaatPelayanan": } \\
\text { "", "umurSekarang": } \\
\text { "51 tahun ,11 bulan } \\
\text {,14 hari" \} }\end{array}$ & $\begin{array}{l}\text { \{ code : } \\
\text { "1:OK", } \\
\text { message : } \\
\text { "Success", } \\
\text { trx_id: } \\
\text { "00000799 } \\
799512017 \\
"\}\end{array}$ & $\begin{array}{l}\text { Nomal } \\
\text { test }\end{array}$ \\
\hline 2. & $\begin{array}{l}\text { Chec } \\
\mathrm{k} \\
\text { dhar } \\
\text { mais } \\
\text { mem } \\
\text { bersh } \\
\text { ip }\end{array}$ & $\begin{array}{l}\text { \{"nobpjs": } \\
\text { "000XXXXXXXXXX } \\
\text { X", "code": "200" } \\
\text { "message": "OK" } \\
\text { "dinsos": null, "iuran" } \\
\text { "", "noSKTM": null } \\
\text { "prolanisPRB": null } \\
\text { "kdJenisPeserta": } \\
\text { "22", } \\
\text { "nmJenisPeserta": } \\
\text { "PBI (APBD)" } \\
\text { "kdKelas": } \quad \text { "3" } \\
\text { "nmKelas": "KELA } \\
\text { III", "nama": "TR } \\
\text { ARNI", "nik": } \\
\text { xxxxxxxxxxxxxxxxxx } \\
\text { ", "noKartu" } \\
\text { "000xxxxxxxxxxx", } \\
\text { "noMr": "151515" }\end{array}$ & $\begin{array}{l}\text { \{code } \\
\text { "0:101", } \\
\text { message : } \\
\text { "Patient } \\
\text { does not } \\
\text { exist", } \\
\text { trx_id: } \\
\text { "null" }\end{array}$ & $\begin{array}{l}\text { Negative } \\
\text { test }\end{array}$ \\
\hline
\end{tabular}




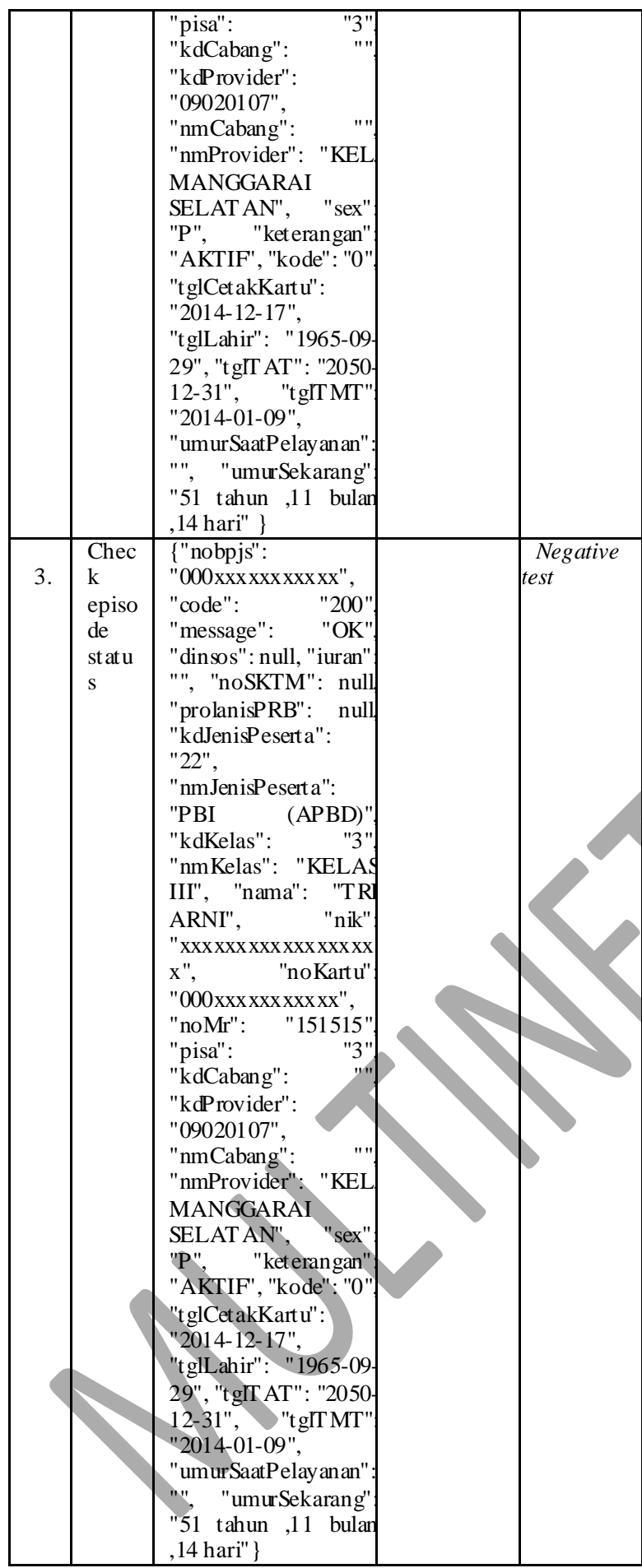

b. Rskdbridge2

URL : <IP address >/DProces sor/rskdbridge2

Fungsi : Membuat SEP, mengirimkan data registrasi ke web service RSKD dan simpan data bridging rskdbridge 2 .
Method : POST

Format : JSON

TABEL 2. TEST CASE OPERASI BRIDGING RSKDBRIDGE2

\begin{tabular}{|c|c|c|c|c|}
\hline No & $\begin{array}{l}\text { Test } \\
\text { Case }\end{array}$ & $\begin{array}{l}\text { Request } \\
\text { Parameter }\end{array}$ & $\begin{array}{l}\text { Response } \\
\text { Message }\end{array}$ & Type \\
\hline 1. & $\begin{array}{l}\text { Rskdbri } \\
\text { dge } 2\end{array}$ & $\begin{array}{l}\text { T"nobpjs": } \\
\text { "000XXXXXXX } \\
\text { XXXX", } \\
\text { "poliT ujuan": } \\
\text { "umum", } \\
\text { "dokter": } \\
\text { "YANTO } \\
\text { CIPUTRA", } \\
\text { trxid": } \\
\text { "000007997995 } 12 \\
017 " \text { " }\end{array}$ & $\begin{array}{l}\{\text { code : } \\
\text { "1:OK", } \\
\text { message : } \\
\text { "Success", }\end{array}$ & $\begin{array}{l}\text { Nom } \\
\text { al test }\end{array}$ \\
\hline 2. & $\begin{array}{l}\text { Create } \\
\text { SEP }\end{array}$ & $\begin{array}{l}\text { \{"nobpjs": } \\
\text { "000XXXXXXX } \\
\text { XXXX ", } \\
\text { "poliT ujuan": } \\
\text { "umum", } \\
\text { "dokter": } \\
\text { "YANTO } \\
\text { CIPUTRA", } \\
\text { "trxid": } \\
\text { "00000799799512 } \\
\text { 017" \} }\end{array}$ & $\begin{array}{l}\{\text { code } \\
\text { "0:101", } \\
\text { message : } \\
\text { "Create SEP } \\
\text { failed", } \\
\}\end{array}$ & $\begin{array}{l}\text { Negative } \\
\text { test }\end{array}$ \\
\hline 3. & $\begin{array}{l}\text { Send } \\
\text { registrat } \\
\text { ion data }\end{array}$ & $\begin{array}{l}\text { \{"nobpjs": } \\
\text { "000XXXXXXX } \\
\text { XXXX", } \\
\text { "poliT ujuan": } \\
\text { "umum", } \\
\text { "dokter": } \\
\text { "YANTO } \\
\text { CIPUTRA", } \\
\text { "trxid": } \\
\text { "00000799799512 } \\
017 " \text { \} }\end{array}$ & $\begin{array}{l}\text { \{code } \\
\text { "0:102", } \\
\text { message } \\
\text { "Send } \\
\text { registration } \\
\text { data failed.", } \\
\}\end{array}$ & $\begin{array}{l}\text { Negati } \\
\text { ve test }\end{array}$ \\
\hline
\end{tabular}

\section{KESIMPULAN DAN SARAN}

\section{A. Kesimpulan}

Kesimpulan dari rancang bangun web service processor untuk sistem KIOSK Medicom. Web service ini dapat menjadi penghubung antara sistem KIOSK Medicom dengan SIM RSKD. Sehingga KIOSK Medicom dapat mengakses dan melakukan pengecekan informasi pasien yang berada dalam SIM RSKD, pengecekan keselesaian tiga status episode dari riwayat kegiatan pasien terdahulu, pendaftaran pasien ke dalam poli tujuan dan dokter yang dipilih, pencetakan SEP, dan penyimpanan data pendaftaran pasien. 


\section{B. Saran}

Sebaiknya dalam pengembangan proyek diketahui user requirement yang matang secara keseluruhan, sehingga dapat mengurangi waktu dalam implementasi dan tidak terjadi penambahan atau perubahan pengerjaan proyek.

\section{REFERENSI}

[1] Anonim. 2017. SOAP Web Services Architecture. https://www.ibm.com/support/knowledgecenter/en/SSGMCP _5.2.0/com.ibm.cics.ts.webservices.doc/concepts/dfhws_mod el.html. [21 Desember 2017].

[2] Taufik, R. dan Utomo, V.G. 2014. "Rancang Bangun Aplikasi Mobile Untuk Notifikasi Jadwal Kuliah Berbasis Android (Studi Kasus: Stmik Provisi Semarang)". Jurnal Teknologi Informasi dan Komunikasi, 48, 2087-0868.

[3] Lewiani, Nia, Lisnawaty dan Akifah. 2017. "Proses Pengelolaan Klaim Pasien BPJS Unit Rawat Inap Rumah Sakit Dr. R. Ismoyo Kota Kendari Tahun 2016". Jurnal Ilmiah Mahasiswa Kesehatan Masy arakat, 4, 250-731.

[4] Mallu, Satriawaty. 2015. "Sistem Pendukung Keputusan Penentuan Karyawan Kontrak Menjadi Karyawan Tetap Menggunakan Metode Topsis". Jurnal Ilmiah Teknologi Informasi Terapan, 38, 2407-3911.

[5] Silvia, A.F., Haritman, E., dan Muladi, Y. 2014. "Rancang Bangun Akses Kontrol Pintu Gerbang Berbasis Arduino dan Android". ELECT RANS, 2, $1412-3762$.

[6] Darminto, E.P. dan Syahriani. 2014. Perancangan Aplikasi Portal Berita E-News Update Berbasis Mobile [Dikutip dari Analisis Dan Perancangan Sistem Basis Data Pada PT Jevin Multi Sarana. Penulisan Ilmiah Fakultas Ilmu Komputer Universitas Binadarma Palembang]. Makalah dipresentasikan pada SNIPTEK 2014.

[7] Setyorini dan Adha, F.A. 2017. "Sistem Informasi Perpustakaan E-Library Stmik Asia Malang Berbasis Java Server Page". Jurnal T eknologi Informasi, 12, 2086-2989.

[8] Imbar, R.V. dan Bratawijaya, P.I.K. 2017. “Sistem Informasi Rekrutmen dan Rekomendasi Penilaian Pelamar Menggunakan ProfileMatching”. JUISI (Vol. 03), 12-13, 2460-1306.

[9] Widanti, Puspa., 2015. Sistem Informasi Laporan Keuangan Penjualan Barang pada CV Vanda Jaya Abadi Tangerang. [Online] Available at: https://widuri.raharja.info/index.php/TA1123368830 [21 Desember 2017].

[10] Novita, R. dan Sari, N. 2015. "Sistem Informasi Penjualan Pupuk Berbasis E-Commerce". Jumal TEKNOIF, 3-4, 23382724.

[11] Object Management Group. 2011. OMG Unified Modelling Language (OMGUML), Superstructure. U.S: Author. 